\title{
Biochemical profile in mixed martial arts athletes
}

\author{
Lukasz Tota ${ }^{\text {Corresp., } 1}$, Szczepan Wiecha ${ }^{2}$ \\ ${ }^{1}$ Department of Physiology and Biochemistry, Faculty of Physical Education and Sport, University of Physical Education in Krakow, Krakow, Poland, \\ Kraków, Polska \\ 2 Department of Physical Education and Health in Biala Podlaska, Jozef Pilsudski, University of Physical Education in Warsaw, Faculty in Biala Podlaska, \\ Biala Podlaska, Poland, Biała Podlaska, Poland \\ Corresponding Author: Lukasz Tota \\ Email address: lukasztota@gmail.com
}

The study aimed to evaluate changes in selected biochemical indicators among mixed martial arts competitors in subsequent periods of the training cycle. The research involved 12 mixed martial arts athletes aged $25.8 \pm 4.2$ years competing in the intermediate category. Selected somatic indicators were measured twice. Biochemical indicators were assessed five times during the 14-week study period. Serum concentrations of testosterone, cortisol, uric acid, myoglobin, total protein, interleukin 6 , and tumor necrosis factor, as well as creatine kinase activity were determined. One hour after sparring completion, there were significant increases in cortisol (by $54.9 \%$ ), uric acid $(22.0 \%)$, myoglobin (565.0\%), and interleukin $6(280.3 \%)$ as compared with the values before the simulated fight. The highest creatine kinase activity $(893.83 \pm 139.31 \mathrm{U} / \mathrm{l})$, as well as tumor necrosis factor $(3.93 \pm 0.71 \mathrm{pg} / \mathrm{ml})$ and testosterone $(5.83 \pm 0.81 \mathrm{ng} / \mathrm{ml}$ ) concentrations ( $p=0.00$ ) were recorded 24 hours after the simulation. Systematic observation of selected blood biochemical indicators in the training process periodization in mixed martial arts helps understand adaptive, compensatory, and regenerative mechanisms occurring in training athletes. 


\section{Biochemical profile in mixed martial arts athletes}

2

3 Łukasz Tota ${ }^{1}$, Szczepan Wiecha ${ }^{2}$

4

$5{ }^{1}$ Department of Physiology and Biochemistry, Faculty of Physical Education and Sport,

6 University of Physical Education in Krakow, Krakow, Poland

$7{ }^{2}$ Department of Physical Education and Health in Biala Podlaska, Jozef Pilsudski University of

8 Physical Education in Warsaw, Faculty in Biala Podlaska, Biala Podlaska, Poland

9

10

11

Corresponding Author:

Łukasz Tota ${ }^{1}$

al. Jana Pawła II 78, 31-571 Krakow, Poland

Email address: lukasztota@gmail.com

\section{Abstract}

The study aimed to evaluate changes in selected biochemical indicators among mixed martial arts competitors in subsequent periods of the training cycle. The research involved 12 mixed martial arts athletes aged $25.8 \pm 4.2$ years competing in the professional (eight participants) and amateur (four participants) category. Selected somatic indicators were measured twice. Biochemical indicators were assessed five times during the 14-week study period. Serum concentrations of testosterone, cortisol, uric acid, myoglobin, total protein, interleukin 6, and tumor necrosis factor, as well as creatine kinase activity were determined. One hour after sparring completion, there were significant increases in myoglobin (565.0\%) and interleukin 6 $(280.3 \%)$ as compared with the values before the simulated fight. The highest creatine kinase activity $(893.83 \pm 139.31 \mathrm{U} / \mathrm{l})$ and tumor necrosis factor concentration $(3.93 \pm 0.71 \mathrm{pg} / \mathrm{ml})(p \leq$ 0.01 ) were recorded 24 hours after the simulation. No significant changes in testosterone, cortisol, or uric acid were found over 14 weeks. Systematic observation of selected blood biochemical indicators in the training process periodization in mixed martial arts helps understand adaptive, compensatory, and regenerative mechanisms occurring in training athletes. 
31 Introduction

32 Mixed martial arts (MMA) is a sport growing in popularity around the world. The competitors

33 must be comprehensively prepared in many aspects of physical fitness (Chernozub et al., 2019).

34 Professional bouts consist of three or five 5-minute rounds, whilst amateur bouts are $3 \times 3$ minute rounds, with the winner determined by a referees' decision after the allotted time or the fight won ahead of time by knockout, technical knockout, submission, or disqualification (Rainey, 2009).

The implementation of training loads, regardless of the sports discipline, leads to metabolic disruptions, which are potent stimuli causing hormonal changes. Understanding the hormonal response to muscle damage and the direction of these changes will allow for a more precise training process control (Philippou et al., 2017).

Exploring and developing new training models is a priority for MMA coaches (Kostikiadis et al., 2018). To better understand the response to physical effort of an intensity similar to that in official sports competitions, simulated combat (sparring) is employed as part of the training process (Amtmann \& Berry, 2003; Kirk et al., 2021). Previous studies with MMA athletes have confirmed acute and chronic changes that result from training load implementation or participation in competitions. However, these were mainly based on the anthropometric profile observation and on tests of physical fitness (Tota et al., 2019a) and salivary osmolality (Vidal Andreato et al., 2014). A number of previous studies analyzed markers of muscle damage during simulated fights, but they failed to relate the magnitude of these indicators to the training period (Ghoul et al., 2019). Much valuable information on recording and evaluating biochemical indicators after competition and sparring is provided by Coswig et al. (2016). A study by Kirk et al. (2020) is a very important source of data that allow to understand the specificity of the MMA sport and that emphasize the need for a close cooperation between the scientific community and sports practitioners. However, the latest research confirms the necessity for further extensive studies with MMA athletes, as the periodization of the training process is largely absent in this group (Kirk et al., 2021).

The applicability of simulated competitions in investigating biochemical responses in training periodization is confirmed by both theoreticians and practitioners of other sports, e.g. judo (Umeda et al., 2008). The necessity to explore biochemical responses in MMA fighters arises from the high demands of the training. The implementation of training loads together with 
62 frequent aggressive strategies aimed at body mass reduction force coaches to employ a large 63 array of biomarkers to streamline the training process (Kasper et al., 2019; Kirk et al., 2021). A

64 better understanding of reaction to exercise helps avoid overtraining and optimize the training by recognizing athletes' individual adaptive and compensatory responses (Chernozub et al., 2019).

The study aim was to evaluate changes in selected biochemical indicators among MMA athletes during the preparation, regeneration, and competition periods.

\section{Materials \& methods}

\section{Characteristics of the investigated competitors}

The study involved 12 MMA athletes aged $25.8 \pm 4.2$ years with an average training experience of $11.8 \pm 2.6$ years. With regard to weight classes, there were four middleweight class fighters, two welterweight class fighters, four lightweight class fighters, and two bantamweight class fighters. They competed in the professional category (eight participants) and in the amateur category (four participants). The professional group represented the following organizations: Ultimate Fighting Championship, Pro MMA Challenge KSW, MMA Attack 3, Fight Exclusive Night, and FCB 9 - Fight Club Berlin 9.

The research protocol was approved by the ethics committee of the regional medical chamber (approval No.: 7/KBL/OIL/2014). The athletes were informed on the study aims and course and provided their written consent to participate, in accordance with the recommendations of the Ethics Committee for Biomedical Research (World Health Organization, 2000). The subjects submitted valid results of their medical examinations.

\section{Study design}

The observation period lasted 14 weeks and was conventionally divided into a preparation period (12 weeks) and a regeneration period (two weeks), after which the athletes took part in a simulated sports fight (competition period). The athletes declared an intensification of the applied training loads during the preparation period and a decrease of the volume and intensity of the training loads in the regeneration period. During the observation period, each athlete implemented eight training units per week (micro-cycle), each lasting 118.5 \pm 19.8 minutes on average. Each micro-cycle included one day off and one day dedicated to wellness, on which the participants visited dry sauna. The average air temperature in the sauna was $95 \pm 5^{\circ} \mathrm{C}$, with a 
93 relative humidity of $8-12 \%$. The athletes reported three phases of warming that lasted $14 \pm 3.0$

94 minutes each and three phases of cooling. The simulated competition consisted of three rounds

95 of 5 minutes each (with 60 -second breaks between the rounds). In accordance with the current

96 MMA rules, the period between the official weigh-in and the fight lasted 24 hours. The average

97 weight loss of the athletes during the analyzed period equaled $3.0 \pm 1.0 \mathrm{~kg}(1.1 \pm 1.3 \mathrm{~kg}$ lean

98 body mass and $1.9 \pm 0.8 \mathrm{~kg}$ fat mass).

99 The athletes' nutrition or hydration were not interfered with throughout the study.

100 Anthropometric measurements were performed at the beginning of the preparation period

101 (series I) and 24 hours before the combat simulation (series III).

102 Biochemical indicators were assessed five times during the 14-week study period: series I

103 - at the beginning of the preparation period; series II - after the 12-week preparation period;

104 series III - after the two-week regeneration period, status before the fight simulation; series IV -

1051 hour after the fight simulation; series V -24 hours after the fight simulation (Fig. 1).

107 [Figure 1 here]

108

\section{Anthropometric evaluation}

110 Body mass and body composition were indicated with a Jawon Medical (model IOI 353, Korea)

111 body composition analyzer and the bioelectrical impedance method. Fat mass and lean body

112 mass were established. Body height was determined to the nearest $1 \mathrm{~mm}$ with a Martin

113 anthropometer (USA).

114

\section{Biochemical evaluation}

116 On the day before the preparation period, after the 12-week training period, after the two-week

117 regeneration period, as well as 1 and 24 hours after the fight simulation, blood samples were

118 collected from a cubital fossa vein by a diagnostician under certified laboratory conditions (PN-

119 EN ISO 9001:2015), in accordance with the applicable standards. The blood was collected into

120 Vacutainer EDTA tubes. Until centrifugation to separate the serum, the blood samples were

121 stored in ice.

122 The immunoassay method (ELISA) and a DRG-type microplate reader (E-Liza Mat 3000,

123 Medical Instruments GmbH, Germany) served to determine the following indicators in the 
124

125

126

127

128

129

130

131

132

133

134

135

136

137

138

139

140

141

142

143

144

145

146

147

148

149

150

151

152

153

154

serum: testosterone (EIA1559), cortisol (EIA1887), uric acid (AB83362), myoglobin (EIA2993), total protein (201-12-1151), creatine kinase (201-12-2091), interleukin 6 (IDEIH-1068), and tumor necrosis factor (IDEIH-1122).

The anabolic/catabolic balance indicator was established with the following formula: testosterone/cortisol $\times 100($ Adlercreutz et al., 1986).

Owing to the potential post-workout dehydration, all biochemical indicators were adjusted. The change in plasma volume (\% $\% \mathrm{PV})$ was established with the formula by Johansen et al. (1998). The Kraemer and Brown (1986) formula served to calculate the adjusted values. All blood analyses were performed by qualified medical personnel.

\section{Competition procedure}

The fights followed the MMA rules with respect to the venue and equipment requirements. The ring was surrounded by five ring ropes; its surface totaled $24 \mathrm{~m}^{2}$. The fights involved professional refereeing. The competitors were divided into pairs, with the consideration of their weight category (difference not exceeding $5 \%$ of body mass) and technical and tactical skills. They performed three 5-minute bouts separated by 1-minute passive regeneration breaks.

\section{Statistical analysis and result presentation}

The statistical analysis was performed with the R software, version 4.1.1. The Shapiro-Wilk test was used to verify the normality of the data distribution. To compare the five time intervals, a one-way repeated ANOVA test was applied or its nonparametric substitute (the Friedman test). We calculated the omega-square effect size $(\omega 2)$ to the ANOVA results for each study parameter. A pairwise $t$-test or pairwise Wilcoxon test (with Bonferroni corrections for multiple testing) served to calculate pairwise comparisons between time intervals.

\section{Results}

A significant $(p \leq 0.01)$ decrease in body mass was recorded in the observation period between series I and III (3.0 $\pm 1.0 \mathrm{~kg}: 1.1 \pm 1.3 \mathrm{~kg}$ lean body mass and $1.9 \pm 0.8 \mathrm{~kg}$ fat mass) (Table 1$).$

\section{[Table 1 here]}


The Shapiro-Wilk test results for particular variables were as follows: $p=0.103$ for

156 cortisol, $p=0.548$ for testosterone, $p=0.379$ for testosterone/cortisol ratio, $p=0.501$ for uric

157 acid, $p=0.001$ for creatine kinase, $p=0.001$ for myoglobin, $p=0.0189$ for interleukin $6, p=$

1580.020 for tumor necrosis factor, and $p=0.032$ for total protein. Table 2 presents the mean values

159 of the athletes' biochemical indicators throughout the observation period. At the beginning of the

160 preparation period (series I) and prior to the commencement of the sparring matches (series III),

161 all analyzed indicators fell within the reference values. One hour after the simulated competition,

162 there were significant $(p \leq 0.01)$ increases - and thus the highest concentrations in the analyzed

163 period - in myoglobin $(122.23 \pm 57.11 \mathrm{ng} / \mathrm{ml})$ and interleukin $6(6.58 \pm 1.43 \mathrm{pg} / \mathrm{ml})$ as compared

164 with the values before the simulated fight (series III). The highest creatine kinase activity

$165(893.83 \pm 139.31 \mathrm{U} / \mathrm{l})$ and tumor necrosis factor concentration $(3.93 \pm 0.71 \mathrm{pg} / \mathrm{ml})(p \leq 0.01)$

166 were recorded 24 hours after the competition simulation. No significant changes were observed

167 in cortisol concentration, testosterone concentration, testosterone/cortisol ratio, or uric acid

168 concentration during the analyzed period (Table 2).

[Table 2 here]

The Shapiro-Wilk test result for changes in plasma volume was $p=0.002$. Plasma volume changed significantly $(p \leq 0.01)$ between the subsequent study stages. The plasma volume changes recorded between the status before the fight simulation (the weigh-in was performed 24 hours before the sports fight, in accordance with the MMA rules) and after the sparring sessions (series III-IV) equaled $-11.81 \pm 5.00 \%$ on average. The plasma volume differences between the assessments obtained 1 hour and 24 hours after the competition amounted to $5.63 \pm 4.83 \%$ (Table 3 ).

[Table 3 here]

\section{Discussion}

The study aimed to characterize MMA competitors' biochemical profile across the successive extensive observation and analysis of biochemical indicators. It is our strong belief that the 
186 results of this study will contribute to a better understanding of training control in MMA fighters.

187 The presented results should help better comprehend such training-related processes as fatigue, 188 recovery, and adaptation. Moreover, our results confirm that MMA is a high-intensity sport and 189 that the concentrations of biomarkers indicating the degree of muscle cell damage in athletes 190 remain high even 24 hours after the competition.

191 Coswig, de P Ramos, and Del Vecchio (2016) compared muscle cell damage in MMA 192 athletes after official and simulated competitions. They demonstrated that similar values of 193 biochemical markers depicting the level of muscle damage could be observed after sparring and 194 after competition. In a sports fight such as the ones in MMA during training and competition, 195 some markers reflecting muscle damage may be related to the number of punches or kicks taken 196 (Wiechmann et al., 2016). The literature repeatedly raises questions about the metabolic profile 197 of MMA athletes. The complexity of training periodization stems simultaneously from the need 198 to develop aerobic and anaerobic capacity and from the continuous training of skills, which 199 include striking (punches, kicks, knee and elbow strikes), power attacks, and elbow attacks (Kirk 200 et al., 2020). An essential element of sports training is the formation of grappling skills (punches, 201 twists, throwing techniques using the legs) and submission on the ground (Kirk, Hurst \& Atkins, 202 2015; Tota et al., 2019a).

203 In MMA, the phenomenon of body mass manipulation through rapid weight loss before 204 fights followed by rapid weight gain is commonly encountered (Kirk, Langan-Evans \& Morton, 205 2020). In isolated cases, it was also observed in the present study: the highest dehydration was 206 recorded before the simulated fight $(\% \Delta \mathrm{PV}=-14.97)$. Numerous studies emphasize high 207 adaptive capacity in elite athletes. It turns out that the reduction in blood and plasma volume due 208 to loss of body mass prior to competition does not affect blood osmolality (Yankanich et al., 209 1998). As a limitation of the present study, the lack of assessing blood osmolality in the 210 particular series should be pointed out, which precludes comparisons with the results of other 211 authors. In the literature, one can find descriptions of planned and long-term (7-week) systematic 212 weight losses (-18.1\% body mass) (Kasper et al., 2019). However, the results of many studies 213 confirm that acute weight cutting is dangerous and harmful to an athlete's health (Matthews \& 214 Nicholas, 2017). This is mainly manifested in the inability to complete cardiac stress tests, 215 endocrine disorders, hypernatremia, and kidney damage (Kasper et al., 2019). It is, though, worth 216 emphasizing that the most recent research does not support the widespread belief of coaches and 
217 athletes concerning the need for rapid weight loss before the official weigh-in followed by rapid

218 weight gain before the competition (Kirk, Langan-Evans \& Morton, 2020).

219 Increased serum glucocorticoid hormone concentration in athletes indicates a normal

220 response to stress stimulus (Walker et al., 2017). In the present study, the highest cortisol

221 concentration $(278.49 \pm 34.42 \mathrm{ng} / \mathrm{ml})$ was recorded 1 hour after completing the fight simulation.

222 No description of changes in this hormone during the preparation period was found in the

223 literature, but the concentration measured after the 12-week preparation period was also high

$224(250.86 \pm 45.98 \mathrm{ng} / \mathrm{ml})$. However, the changes in cortisol concentration during the analyzed

225 period proved to be statistically insignificant. Different results were obtained by Ghoul et al.

226 (2019) among 12 MMA athletes, who presented the highest cortisol concentrations directly after

227 the simulated competition. Lindsay et al. (2017) demonstrated that immediate post-exercise

228 immersion in cold water resulted in a faster decline in this hormone levels among MMA athletes.

229 Therefore, further research should focus on accelerating regeneration processes, which can

230 largely contribute to reducing the risk of injury in athletes.

231 Testosterone is involved in the restoration of damaged skeletal muscles, influencing the

232 fusion of myoblasts forming multinucleated myotubes which give rise to muscle fibers. Myoblast

233 fusion constitutes a key phase of muscle regeneration after physical effort (Husak \& Irschick,

234 2009). Incorporating resistance/strength exercise into physical training increases testosterone

235 concentration and satellite cell counts (Mackey et al., 2007). Monitoring changes in serum

236 testosterone levels is often adopted among strength sports athletes. A decrease in the blood

237 concentration of this hormone indicates processes of long-term adaptation to anaerobic power

238 loads in athletes practicing fitness (Chernozub, 2013). In our study, the greatest decrease in

239 testosterone concentration was reported 1 hour after completing the fight simulation. However, it

240 should be noted that throughout the observation period, changes in testosterone levels were not

241 statistically significant. Changes in testosterone concentrations due to the implemented training

242 loads are most likely related to the inhibition of the hypothalamic-pituitary-adrenal axis.

243 Sustained inflammation and increased catabolism may inhibit this hormone secretion (Kraemer

244 et al., 2001). An imbalance between physical training and rest periods results in reduced physical

245 capacity, severe fatigue, and even overtraining (Pankanin, 2018). We did not observe a decrease

246 in testosterone concentration resulting from dehydration before the official weigh-in (series III)

247 as other authors have (Coswig, Fukuda \& Del Vecchio, 2015). This is most likely due to a too 
248 little weight loss in our athletes $(-3.9 \%)$ as compared with the one described elsewhere $(-10.0 \%$

249 body mass) (Coswig, Fukuda \& Del Vecchio, 2015).

250 Training periodization involves evaluating testosterone and cortisol concentrations and

251 determining their ratio (testosterone/cortisol). Decreases in this ratio occur in athletes practicing

252 various disciplines both after competitions and after several weeks of training (Marques et al.,

253 2017; Tota et al., 2019b). A simultaneous increase in cortisol concentration and decrease in

254 testosterone concentration may further intensify catabolic processes at the tissue level, thus

255 reducing muscle strength and overall body capacity (Barbas et al., 2011). The lowest

256 testosterone/cortisol ratio values observed in the present study occurred when measured in series

257 II (after a 12-week preparation period), in series IV (1 hour after the simulated fight), and in

258 series V (24 hours after the simulated fight).

259 Exercise-induced muscle cell damage triggers a repair response, macrophage entry into

260 muscles, and an increase in interleukin 6. The changes in this cytokine concentration in the

261 subsequent training periods in this study correspond with the observations by other authors

262 (Barbas et al., 2011). A significant increase in interleukin 6 concentration (by 280.3\%) 1 hour

263 after the competition indicated a rapid inflammatory response induced by high-intensity physical

264 activity during sparring.

265 The high uric acid concentration after the simulated combat $(363.51 \pm 53.22 \mu \mathrm{mol} / 1)$ is

266 due to increased purine nucleotide degradation and damage to fast-twitch fibers under conditions

267 of high energy demand. The elevated concentration of this marker may indicate a shift in the

268 metabolic balance towards catabolic transformations accompanied by the breakdown of proteins

269 and high-energy molecules and the release of free radicals. The high values reached after the

270 preparation period $(337.53 \pm 44.30 \mu \mathrm{mol} / \mathrm{l})$ and after sparring may result from the high-intensity

271 and high-volume exercise loads applied. They may also be due to insufficient hydration. The

272 changes in uric acid concentration in the subsequent series of the study, confirmed by other

273 authors (Ghoul et al., 2019), imply that high levels of anaerobic capacity are required from

274 MMA competitors, which should be considered in training periodization.

275 High uric acid concentrations are accompanied by high creatine kinase activity. The

276 highest increase in creatine kinase activity (by 625.2\%) was observed 24 hours after sparring

277 compared with the value recorded before the competition. Reaching the peak level of this

278 enzyme 24 hours after the competition is in line with the findings by Coswig, de P Ramos, and

Peer] reviewing PDF | (2021:09:65802:2:0:NEW 7 Dec 2021) 
279 Del Vecchio (2016). The high mean creatine kinase activity after the preparation period (490.36

$280 \mathrm{U} / \mathrm{l})$ and after sparring (607.97 U/1) may indicate muscle cell damage caused by intense physical

281 effort - which, according to athletes, is encountered during sparring and wrestling sparring

282 (rating of perceived exertion: $\geq 7$ ) (Kirk et al., 2021) - and by possible injuries induced by

283 punching (Cordeiro et al., 2007). Clarkson et al. (2006) concluded that an increase in creatine

284 kinase activity above 20,000 U/1 after very intense physical effort did not require

285 pharmacological treatment to prevent kidney damage. However, dehydration, a common

286 condition in MMA, is a key factor increasing the risk of kidney damage by reducing myoglobin

287 solubility (Jetton et al., 2013). The changes in myoglobin concentration during the observation

288 period were most likely related to the increased metabolic stress resulting from the high-intensity

289 physical effort implemented during the preparation and competition periods (Ghoul et al., 2019).

290 As in the study by Coswig et al. (2016), we believe that changes in myoglobin concentration can

291 be a useful biomarker employed to streamline the training process in MMA.

292

293 Conclusions

294 The biomarker changes (concerning myoglobin, tumor necrosis factor, creatine kinase, and

295 interleukin 6) in training periodization allow to hypothesize that observing the direction of these

296 changes may prove crucial in monitoring compensation, regeneration, and supercompensation. In

297 the context of muscle damage, these observations may enable a more precise control of the

298 training process (Philippou et al., 2017). Nevertheless, further research is necessary to assess the

299 impact of different forms of regeneration on recovery acceleration (Lindsay et al., 2017). The

300 authors are aware of the study limitations, including no training load recording during the

301 observation period and the focus only on the number and duration of the implemented training

302 units. It is also worth noting that the weight loss in the experiment participants was certainly

303 lower than that often seen in MMA athletes before their fights at combat sports shows. One can

304 assume that the lack of rapid weight loss in our athletes did not cause a negative effect of

305 dehydration on the investigated biochemical parameters, which was reported by other authors

306 (Coswig, Fukuda \& Del Vecchio, 2015). Therefore, the observed changes resulted from the

307 implementation of training loads rather than acute weight cutting. Furthermore, technical or

308 tactical actions during the simulation were not analyzed, unlike in some other studies (Coswig,

309 de P Ramos \& Del Vecchio, 2016). However, numerous such descriptions are found in the 
310 literature, in contrast to the coverage of changes in biochemical indicators during preparation,

311 regeneration, and competition periods. This study aimed to investigate MMA athletes'

312 biochemical profile in the preparation and competition periods. Observing changes in selected

313 biomarkers helps diagnose the training loads in particular training cycle periods. The presented

314 data confirm that MMA is a high-intensity combat sport and the concentrations of biomarkers

315 reflecting the degree of muscle cell damage (myoglobin, tumor necrosis factor, creatine kinase,

316 and interleukin 6) remain high even 24 hours after the competition.

317

318

References

319 Adlercreutz H, Härkönen M, Kuoppasalmi K, Näveri H, Huhtaniemi I, Tikkanen H, Remes K,

320 Dessypris A, Karvonen J. 1986. Effect of training on plasma anabolic and catabolic steroid hormones and their response during physical exercise. International Journal of Sports

322 Medicine 7(Suppl. 1):27-28 DOI: 10.1055/s-2008-1025798

Amtmann J, Berry S. 2003. Strength and conditioning for reality fighting. Strength \& Conditioning Journal 25(2):67-72 DOI: 10.1519/00126548-200304000-00012

Barbas I, Fatouros IG, Douroudos II, Chatzinikolaou A, Michailidis Y, Draganidis D, Jamurtas wrestlers during a one-day tournament. European Journal of Applied Physiology

$$
\text { 111(7):1421-1436 DOI: 10.1007/s00421-010-1761-7 }
$$

Chernozub AA. 2013. Changing the content of testosterone in the blood of people of different level of fitness in terms of power load. Vestnik Rossiiskoi Akademii Meditsinskikh Nauk

$$
\text { 10:37-40 DOI: 10.15690/vramn.v68i10.786 }
$$

Chernozub A, Danylchenko S, Imas Y, Kochina M, Ieremenko N, Korobeynikov G, Korobeynikova L, Potop V, Cynarski WJ, Gorashchenco A. 2019. Peculiarities of correcting 339 load parameters in power training of mixed martial arts athletes. Journal of Physical Education and Sport 19(Suppl. 2):481-488 DOI: 10.7752/jpes.2019.s2070

Clarkson PM, Kearns AK, Rouzier P, Rubin R, Thompson PD. 2006. Serum creatine kinase levels and renal function measures in exertional muscle damage. Medicine \& Science in Sports \& Exercise 38(4):623-627 DOI: 10.1249/01.mss.0000210192.49210.fc 
340 Cordeiro EM, Gomes ALM, Guimarães M, da Silva SG, Dantas EHM. 2007. Haematological

341 and biochemical alterations originating from the combat training in Olympic kung fu athletes.

342 Fitness \& Performance Journal 6(4):255-261 DOI: 10.3900/fpj.6.4.255.e

343 Coswig VS, de P Ramos S, Del Vecchio FB. 2016. Time-motion and biological responses in

344 simulated mixed martial arts sparring matches. Journal of Strength and Conditioning

345 Research 30(8):2156-2163 DOI: 10.1519/JSC.0000000000001340

346 Coswig VS, Fukuda DH, de P Ramos S, Del Vecchio FB. 2016. Biochemical differences

347 between official and simulated mixed martial arts (MMA) matches. Asian Journal of Sports

348 Medicine 7(2):e30950 DOI: 10.5812/asjsm.30950

349 Coswig VS, Fukuda DH, Del Vecchio FB. 2015. Rapid weight loss elicits harmful biochemical

350 and hormonal responses in mixed martial arts athletes. International Journal of Sport

351 Nutrition and Exercise Metabolism 25(5):480-486 DOI: 10.1123/ijsnem.2014-0267

352 Ghoul N, Tabben M, Miarka B, Tourny C, Chamari K, Coquart J. 2019. Mixed martial arts

353 induces significant fatigue and muscle damage up to 24 hours post-combat. Journal of

354 Strength and Conditioning Research 33(6):1570-1579 DOI: 10.1519/JSC.0000000000002078

355 Husak JF, Irschick DJ. 2009. Steroid use and human performance: lessons for integrative

356 biologist. Integrative and Comparative Biology 49(4):354-364 DOI: 10.1093/icb/icp015

357 Jetton AM, Lawrence MM, Meucci M, Haines TL, Collier SR, Morris DM, Utter AC. 2013.

358 Dehydration and acute weight gain in mixed martial arts fighters before competition. Journal

359 of Strength and Conditioning Research 27(5):1322-1326 DOI:

$360 \quad$ 10.1519/JSC.0b013e31828a1e91

361 Johansen LB, Videbaek R, Hammerum M, Norsk P. 1998. Underestimation of plasma volume

362 changes in humans by hematocrit/hemoglobin method. American Journal of Physiology

363 274(1):R126-R130 DOI: 10.1152/ajpregu.1998.274.1.R126

364

365

366

367

368

369

370

Kasper AM, Crighton B, Langan-Evans C, Riley P, Sharma A, Close GL, Morton JP. 2019. Case study: extreme weight making causes relative energy deficiency, dehydration, and acute kidney injury in a male mixed martial arts athlete. International Journal of Sport Nutrition and Exercise Metabolism 29(3):331-338 DOI: 10.1123/ijsnem.2018-0029

Kirk C, Clark DR, Langan-Evans C, Morton JP. 2020. The physical demands of mixed martial arts: a narrative review using the ARMSS model to provide a hierarchy of evidence. Journal of Sports Sciences 38(24):2819-2841 DOI: 10.1080/02640414.2020.1802093 
371 Kirk C, Hurst HT, Atkins S. 2015. Measuring the workload of mixed martial arts using

372 accelerometry, time motion analysis and lactate. International Journal of Performance

373 Analysis in Sport 15(1):359-370 DOI: 10.1080/24748668.2015.11868798

374 Kirk C, Langan-Evans C, Clark DR, Morton JP. 2021. Quantification of training load

375 distribution in mixed martial arts athletes: a lack of periodisation and load management. PLoS

376 One 16(5):e251266 DOI: 10.1371/journal.pone.0251266

377 Kirk C, Langan-Evans C, Morton JP. 2020. Worth the weight? Post weigh-in rapid weight gain is not related to winning or losing in professional mixed martial arts. International Journal of Sport Nutrition and Exercise Metabolism 30(5):357-361 DOI: 10.1123/ijsnem.2019-0347

Kostikiadis IN, Methenitis S, Tsoukos A, Veligekas P, Terzis G, Bogdanis GC. 2018. The effect of short-term sport-specific strength and conditioning training on physical fitness of well-

Kraemer RR, Brown BS. 1986. Alterations in plasma-volume-corrected blood components of marathon runners and concomitant relationship to performance. European Journal of Applied Physiology and Occupational Physiology 55(6):579-584 DOI: 10.1007/BF00423200

Kraemer WJ, Fry AC, Rubin MR, Triplett-McBride T, Gordon SE, Koziris LP, Lynch JM, Volek JS, Meuffels DE, Newton RU, Fleck SJ. 2001. Physiological and performance responses to tournament wrestling. Medicine \& Science in Sports \& Exercise 33(8):1367-1378 DOI: 10.1097/00005768-200108000-00019

Lindsay A, Carr S, Cross S, Petersen C, Lewis JG, Gieseg SP. 2017. The physiological response to cold-water immersion following a mixed martial arts training session. Applied Physiology, Nutrition, and Metabolism 42(5):529-536 DOI: 10.1139/apnm-2016-0582

Mackey AL, Kjaer M, Dandanell S, Mikkelsen KH, Holm L, Døssing S, Kadi F, Koskinen SO, Jensen CH, Schrøder HD, Langberg H. 2007. The influence of anti-inflammatory medication on exercise-induced myogenic precursor cell responses in humans. Journal of Applied Physiology 103(2):425-431 DOI: 10.1152/japplphysiol.00157.2007

Marques L, Franchini E, Drago G, Aoki MS, Moreira A. 2017. Physiological and performance changes in national and international judo athletes during block periodization training. Biology of Sport 34(4):371-378 DOI: 10.5114/biolsport.2017.69825 
400

401

402

403

404

405

406

407

408

409

410

411

412

413

414

415

416

417

418

419

420

421

422

423

424

425

426

427

428

429

Matthews JJ, Nicholas C. 2017. Extreme rapid weight loss and rapid weight gain observed in UK mixed martial arts athletes preparing for competition. International Journal of Sport Nutrition and Exercise Metabolism 27(2):122-129 DOI: 10.1123/ijsnem.2016-0174

Pankanin E. 2018. Overreaching and overtraining syndrome - causes, symptoms, diagnostics and prevention. Journal of Education, Health and Sport 8(7):424-429 DOI:

\subsection{1/zenodo. 1325370}

Philippou A, Maridaki M, Tenta R, Koutsilieris M. 2017. Hormonal responses following eccentric exercise in humans. Hormones 16(4):405-413 DOI: 10.14310/horm.2002.1761

Rainey CE. 2009. Determining the prevalence and assessing the severity of injuries in mixed martial arts athletes. North American Journal of Sports Physical Therapy 4(4):190-199

Tota L, Pilch W, Piotrowska A, Maciejczyk M. 2019a. The effects of conditioning training on body build, aerobic and anaerobic performance in elite mixed martial arts athletes. Journal of Human Kinetics 70:223-231 DOI: 10.2478/hukin-2019-0033

Tota Ł, Piotrowska A, Pałka T, Morawska M, Mikuláková W, Mucha D, Żmuda-Pałka M, Pilch W. 2019b. Muscle and intestinal damage in triathletes. PLoS One 14(1):e0210651 DOI: 10.1371/journal.pone.0210651

Umeda T, Yamai K, Takahashi I, Kojima A, Yamamoto Y, Tanabe M, Totsuka M, Nakaji S, Sugawara N, Matsuzaka M. 2008. The effects of a two-hour judo training session on the neutrophil immune functions in university judoists. Journal of Luminescence 23(1):49-53 DOI: 10.1002/bio.1016

Vidal Andreato L, Vidal Andreato T, Ferreira da Silva Santos J, Del Conti Esteves JV, Franzói de Moraes SM, Franchini E. 2014. Weight loss in mixed martial arts athletes. Journal of Combat Sports and Martial Arts 5(2):125-131 DOI: 10.5604/20815735.1141986

Walker S, Häkkinen K, Haff GG, Blazevich AJ, Newton RU. 2017. Acute elevations in serum hormones are attenuated after chronic training with traditional isoinertial but not accentuated eccentric loads in strength-trained men. Physiological Reports 5(7):e13241 DOI: $10.14814 /$ phy 2.13241

Wiechmann GJ, Saygili E, Zilkens C, Krauspe R, Behringer M. 2016. Evaluation of muscle damage marker after mixed martial arts matches. Orthopedic Reviews 8(1):6209 DOI: 10.4081/or.2016.6209 
430 World Health Organization. 2000. Operational guidelines for ethics committees that review

431 biomedical research. Genewa: World Health Organization. Available at

432 https://apps.who.int/iris/bitstream/handle/10665/66429/TDR_PRD_ETHICS_2000.1_pol.pdf?

433 sequence $=9 \&$ isAllowed $=\mathrm{y}($ accessed 5 April 2021)

434 Yankanich J, Kenney WL, Fleck SJ, Kraemer WJ. 1998. Precompetition weight loss and changes

435 in vascular fluid volume in NCAA Division I college wrestlers. Journal of Strength and

436 Conditioning Research 12(3):138-145 DOI: 10.1519/00124278-199808000-00002

437 
Figure 1

Study design flowchart

Study design flowchart 


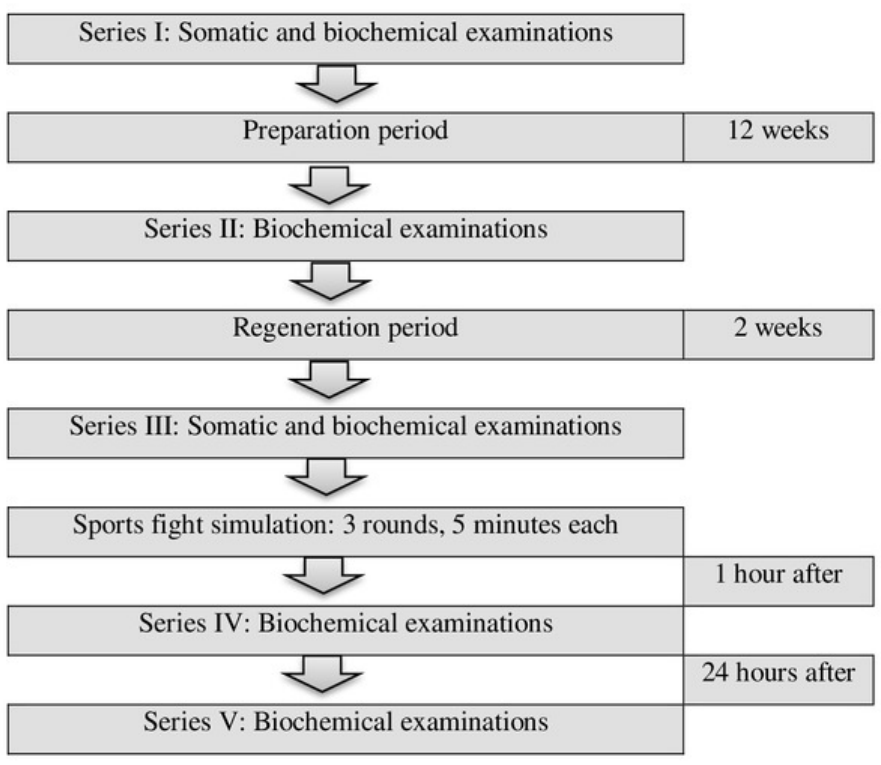




\section{Table $\mathbf{1}$ (on next page)}

Table 2

Selected biochemical indicators in the mixed martial arts athletes in the observation period. 
Ta⿱⺈⿵⺆⿻二丨凵口:

\section{Manuscript to be reviewed}

Selected biochemical indicators in the mixed martial arts athletes in the observation period.

\begin{tabular}{|c|c|c|c|c|c|c|}
\hline & Series I & Series II & Series III & Series IV & Series V & $\begin{array}{l}\text { Effect size: } \\
\text { omega }^{2} \text { CI }\end{array}$ \\
\hline $\begin{array}{l}\text { Cortisol } \\
{[\mathrm{ng} / \mathrm{ml}]}\end{array}$ & $\begin{array}{l}168.71 \pm \\
41.66\end{array}$ & $\begin{array}{l}250.86 \pm \\
45.98\end{array}$ & $\begin{array}{l}179.77 \pm \\
40.17\end{array}$ & $\begin{array}{l}278.49 \pm \\
34.42\end{array}$ & $208.43 \pm 47.12$ & \multirow[t]{2}{*}[0.26;0.61]{} \\
\hline$p$ & \multicolumn{5}{|l|}{0.103} & \\
\hline $\begin{array}{l}\text { Testosterone } \\
{[\mathrm{ng} / \mathrm{ml}]}\end{array}$ & $4.97 \pm 0.60$ & $5.50 \pm 0.70$ & $5.74 \pm 0.65$ & $5.23 \pm 0.46$ & $5.83 \pm 0.81$ & $\begin{array}{c}\underline{0.14} \\
{[0.00,0.28]} \\
\end{array}$ \\
\hline$p$ & \multicolumn{5}{|l|}{0.548} & \multirow{3}{*}{$\begin{array}{c}0.36 \\
{[0.13,0.51]}\end{array}$} \\
\hline $\begin{array}{l}\text { Testosterone/ } \\
\text { cortisol index }\end{array}$ & $3.11 \pm 0.82$ & $2.26 \pm 0.45$ & $3.36 \pm 0.90$ & $1.93 \pm 0.28$ & $2.18 \pm 0.55$ & \\
\hline$p$ & \multicolumn{5}{|l|}{0.379} & \\
\hline $\begin{array}{l}\text { Uric acid } \\
{[\mu \mathrm{mol} / \mathrm{l}]}\end{array}$ & $\begin{array}{l}300.69 \pm \\
43.48\end{array}$ & $\begin{array}{l}337.53 \pm \\
44.30\end{array}$ & $\begin{array}{l}297.86 \pm \\
35.10\end{array}$ & $\begin{array}{l}363.51 \pm \\
53.22\end{array}$ & $302.99 \pm 38.59$ & \multirow[t]{2}{*}{$\begin{array}{c}0.22 \\
{[0.02,0.38]}\end{array}$} \\
\hline$p$ & \multicolumn{5}{|l|}{0.501} & \\
\hline $\begin{array}{l}\text { Creatine kinase } \\
{[\mathrm{U} / \mathrm{l}]}\end{array}$ & $\begin{array}{l}106.51 \pm \\
27.44\end{array}$ & $\begin{array}{l}490.36 \pm \\
133.60\end{array}$ & $\begin{array}{l}123.12 \pm \\
23.21\end{array}$ & $\begin{array}{l}607.97 \pm \\
90.96\end{array}$ & $\begin{array}{l}893.83 \pm \\
139.31\end{array}$ & \multirow[t]{2}{*}{$\begin{array}{c}0.90 \\
{[0.86,0.93]}\end{array}$} \\
\hline$p$ & \multicolumn{5}{|c|}{ Series I-II: $p \leq 0.01 *$; series II-III: $p \leq 0.01 *$; series III-IV: $p \leq 0.01^{*}$; series IV-V: $p \leq 0.01^{*}$} & \\
\hline $\begin{array}{l}\text { Myoglobin } \\
{[\mathrm{ng} / \mathrm{ml}]}\end{array}$ & $16.03 \pm 3.57$ & $42.43 \pm 18.78$ & $18.38 \pm 3.01$ & $\begin{array}{l}122.23 \pm \\
57.11\end{array}$ & $33.43 \pm 10.50$ & \multirow[t]{2}{*}{$\begin{array}{c}0.66 \\
{[0.50,0.76]}\end{array}$} \\
\hline$p$ & \multicolumn{5}{|c|}{ Series I-II: $p \leq 0.01^{*}$; series II-III: $p \leq 0.01^{*}$; series III-IV: $p \leq 0.01 *$; series IV-V: $p \leq 0.01^{*}$} & \\
\hline $\begin{array}{l}\text { Interleukin } 6 \\
{[\mathrm{pg} / \mathrm{ml}]}\end{array}$ & $1.57 \pm 0.52$ & $3.94 \pm 1.34$ & $1.73 \pm 0.60$ & $6.58 \pm 1.43$ & $3.01 \pm 1.02$ & \multirow[t]{2}{*}{$\begin{array}{c}0.75 \\
{[0.62,0.82]}\end{array}$} \\
\hline$p$ & \multicolumn{5}{|c|}{ Series I-II: $p \leq 0.01^{*}$; series II-III: $p \leq 0.01^{*}$; series III-IV: $p \leq 0.01 *$; series IV-V: $p \leq 0.01^{*}$} & \\
\hline $\begin{array}{l}\text { Tumor necrosis } \\
\text { factor } \alpha[\mathrm{pg} / \mathrm{ml}]\end{array}$ & $2.45 \pm 0.45$ & $2.64 \pm 0.42$ & $2.18 \pm 0.35$ & $2.84 \pm 0.52$ & $3.93 \pm 0.71$ & \multirow{2}{*}{$\begin{array}{c}0.57 \\
{[0.28,0.69]}\end{array}$} \\
\hline$p$ & \multicolumn{5}{|c|}{ Series I-II: $p=0.03^{*}$; series II-III: $p=0.04^{*}$; series III-IV $: p=0.03^{*}$; series IV-V: $p=0.02 *$} & \\
\hline $\begin{array}{l}\text { Total protein } \\
{[\mathrm{g} / \mathrm{l}]}\end{array}$ & $69.43 \pm 3.66$ & $70.56 \pm 5.19$ & $73.17 \pm 4.12$ & $83.14 \pm 5.32$ & $69.33 \pm 3.68$ & \multirow[t]{2}{*}{$\begin{array}{c}0.56 \\
{[0.37,0.68]}\end{array}$} \\
\hline$p$ & \multicolumn{5}{|c|}{ Series I-II: $p=1.00$; series II-III: $p=0.29$; series III-IV: $p \leq 0.01^{*}$; series IV-V: $p \leq 0.01^{*}$} & \\
\hline
\end{tabular}

Notes:

Series I: Assessment before the preparation period; Series II: Assessment after the 12-week preparation period; Series III: Assessment after the two-week regeneration period, status before the fight; Series IV: Assessment 1 hour after the fight; Series V: Assessment 24 hours after the fight Explanations:

* Statistically significant $p \leq 0.05$. Effect size: omega ${ }^{2}$ CI - omega squared $(\omega 2)$ effect sizes to the ANOVA results for every parameter tested 


\section{Table 2 (on next page)}

Changes in selected somatic indicators in the examined athletes.

BM: Body mass; BH: Body height; LBM: Lean body mass; FM: Fat mass; \%F: Body fat percentage; Series I: Assessment before the preparation period; Series III: Assessment before the sports fight simulation Explanations: * Statistically significant $p \leq 0.05$. 


\section{Table 3(on next page)}

Plasma volume changes ( $\% \Delta \mathrm{PV})$ in the subsequent study stages.

Series I: Assessment before the preparation period; Series II: Assessment after the 12week preparation period; Series III: Assessment after the two-week regeneration period, status before the fight; Series IV: Assessment 1 hour after the fight; Series V: Assessment 24 hours after the fight Explanations: * Statistically significant $p \leq 0.05$. 
1 Table 3:

2 Plasma volume changes $(\% \Delta P V)$ in the subsequent study stages.

\begin{tabular}{|l|l|l|l|l|}
\hline Series & I-II & II-III & III-IV & III-V \\
\hline$\% \Delta \mathrm{PV}$ & $-1.29 \pm 6.31$ & $-14.97 \pm 6.35$ & $-11.81 \pm 5.00$ & $5.63 \pm 4.83$ \\
\hline$p$ & I-II and II-III: $p \leq 0.01^{*} ;$ II-III and III-IV: $p \leq 0.01^{*} ;$ III-IV and IV-V: $p \leq 0.01^{*}$ \\
\hline
\end{tabular}

3 Notes:

4 Series I: Assessment before the preparation period; Series II: Assessment after the 12-week

5 preparation period; Series III: Assessment after the two-week regeneration period, status before

6 the fight; Series IV: Assessment 1 hour after the fight; Series V: Assessment 24 hours after the

7 fight

8 Explanations:

$9 *$ Statistically significant $p \leq 0.05$. 


\section{Table 4(on next page)}

Table 2-accepted changes

Selected biochemical indicators in the mixed martial arts athletes in the observation period. 


\section{Table 2:}

2 Selected biochemical indicators in the mixed martial arts athletes in the observation period.

\begin{tabular}{|c|c|c|c|c|c|c|}
\hline & Series I & Series II & Series III & Series IV & Series V & $\begin{array}{l}\text { Effect size: } \\
\text { omega }^{2} \text { CI }\end{array}$ \\
\hline $\begin{array}{l}\text { Cortisol } \\
{[\mathrm{ng} / \mathrm{ml}]}\end{array}$ & $\begin{array}{l}168.71 \pm \\
41.66\end{array}$ & $\begin{array}{l}250.86 \pm \\
45.98\end{array}$ & $\begin{array}{l}179.77 \pm \\
40.17\end{array}$ & $\begin{array}{l}278.49 \pm \\
34.42\end{array}$ & $208.43 \pm 47.12$ & \multirow[t]{2}{*}{$\begin{array}{c}0.48 \\
{[0.26 ; 0.61]}\end{array}$} \\
\hline$p$ & \multicolumn{5}{|l|}{0.103} & \\
\hline $\begin{array}{l}\text { Testosterone } \\
{[\mathrm{ng} / \mathrm{ml}]}\end{array}$ & $4.97 \pm 0.60$ & $5.50 \pm 0.70$ & $5.74 \pm 0.65$ & $5.23 \pm 0.46$ & $5.83 \pm 0.81$ & \multirow[t]{2}{*}{$\begin{array}{c}0.14 \\
{[0.00,0.28]}\end{array}$} \\
\hline$p$ & \multicolumn{5}{|l|}{0.548} & \\
\hline $\begin{array}{l}\text { Testosterone/ } \\
\text { cortisol index }\end{array}$ & $3.11 \pm 0.82$ & $2.26 \pm 0.45$ & $3.36 \pm 0.90$ & $1.93 \pm 0.28$ & $2.18 \pm 0.55$ & \multirow[t]{2}{*}{$\begin{array}{c}0.36 \\
{[0.13,0.51]}\end{array}$} \\
\hline$p$ & \multicolumn{5}{|l|}{0.379} & \\
\hline $\begin{array}{l}\text { Uric acid } \\
{[\mu \mathrm{mol} / \mathrm{l}]}\end{array}$ & $\begin{array}{l}300.69 \pm \\
43.48\end{array}$ & $\begin{array}{l}337.53 \pm \\
44.30\end{array}$ & $\begin{array}{l}297.86 \pm \\
35.10\end{array}$ & $\begin{array}{l}363.51 \pm \\
53.22\end{array}$ & $302.99 \pm 38.59$ & \multirow[t]{2}{*}{$\begin{array}{c}0.22 \\
{[0.02,0.38]}\end{array}$} \\
\hline$p$ & \multicolumn{5}{|l|}{0.501} & \\
\hline $\begin{array}{l}\text { Creatine kinase } \\
{[\mathrm{U} / 1]}\end{array}$ & $\begin{array}{l}106.51 \pm \\
27.44\end{array}$ & $\begin{array}{l}490.36 \pm \\
133.60\end{array}$ & $\begin{array}{l}123.12 \pm \\
23.21\end{array}$ & $\begin{array}{l}607.97 \pm \\
90.96\end{array}$ & $\begin{array}{l}893.83 \pm \\
139.31\end{array}$ & \multirow[t]{2}{*}{$\begin{array}{c}0.90 \\
{[0.86,0.93]}\end{array}$} \\
\hline$p$ & \multicolumn{5}{|c|}{ Series I-II: $p \leq 0.01 *$; series II-III: $p \leq 0.01^{*}$; series III-IV: $p \leq 0.01 *$; series IV-V: $p \leq 0.01^{*}$} & \\
\hline $\begin{array}{l}\text { Myoglobin } \\
{[\mathrm{ng} / \mathrm{ml}]}\end{array}$ & $16.03 \pm 3.57$ & $42.43 \pm 18.78$ & $18.38 \pm 3.01$ & $\begin{array}{l}122.23 \pm \\
57.11\end{array}$ & $33.43 \pm 10.50$ & \multirow[t]{2}{*}{$\begin{array}{c}0.66 \\
{[0.50,0.76]}\end{array}$} \\
\hline$p$ & \multicolumn{5}{|c|}{ Series I-II: $p \leq 0.01 *$; series II-III: $p \leq 0.01^{*}$; series III-IV: $p \leq 0.01 *$; series IV-V: $p \leq 0.01^{*}$} & \\
\hline $\begin{array}{l}\text { Interleukin } 6 \\
{[\mathrm{pg} / \mathrm{ml}]}\end{array}$ & $1.57 \pm 0.52$ & $3.94 \pm 1.34$ & $1.73 \pm 0.60$ & $6.58 \pm 1.43$ & $3.01 \pm 1.02$ & \multirow[t]{2}{*}{$\begin{array}{c}0.75 \\
{[0.62,0.82]}\end{array}$} \\
\hline$p$ & \multicolumn{5}{|c|}{ Series I-II: $p \leq 0.01^{*}$; series II-III: $p \leq 0.01 *$; series III-IV: $p \leq 0.01 *$; series IV-V: $p \leq 0.01^{*}$} & \\
\hline $\begin{array}{l}\text { Tumor necrosis } \\
\text { factor } \alpha[\mathrm{pg} / \mathrm{ml}]\end{array}$ & $2.45 \pm 0.45$ & $2.64 \pm 0.42$ & $2.18 \pm 0.35$ & $2.84 \pm 0.52$ & $3.93 \pm 0.71$ & \multirow[t]{2}{*}{$\begin{array}{c}0.57 \\
{[0.28,0.69]}\end{array}$} \\
\hline$p$ & \multicolumn{5}{|c|}{ Series I-II: $p=0.03^{*} ;$ series II-III: $p=0.04 *$; series III-IV: $p=0.03^{*}$; series IV-V: $p=0.02 *$} & \\
\hline $\begin{array}{l}\text { Total protein } \\
{[\mathrm{g} / \mathrm{l}]}\end{array}$ & $69.43 \pm 3.66$ & $70.56 \pm 5.19$ & $73.17 \pm 4.12$ & $83.14 \pm 5.32$ & $69.33 \pm 3.68$ & \multirow[t]{2}{*}{$\begin{array}{c}0.56 \\
{[0.37,0.68]}\end{array}$} \\
\hline$p$ & \multicolumn{5}{|c|}{ Series I-II: $p=1.00$; series II-III: $p=0.29$; series III-IV: $p \leq 0.01^{*}$; series IV-V: $p \leq 0.01^{*}$} & \\
\hline
\end{tabular}

3 Notes:

4 Series I: Assessment before the preparation period; Series II: Assessment after the 12-week

5 preparation period; Series III: Assessment after the two-week regeneration period, status before

6 the fight; Series IV: Assessment 1 hour after the fight; Series V: Assessment 24 hours after the

7 fight 
8 Explanations:

9 * Statistically significant $p \leq 0.05$. Effect size: omega ${ }^{2}$ CI - omega squared $(\omega 2)$ effect sizes to 10 the ANOVA results for every parameter tested

11 